\title{
Świat wirtualny miejscem nawiązywania i utrzymywania relacji przez młodzież
}

DOI: $10.47050 / 65591777.68-89$

Anna Andrzejewska

Obszar, w którym funkcjonuje człowiek, ulega ciągłym zmianom, co jest naturalnym procesem. Ostatnie lata to dynamiczny rozwój przestrzeni cyfrowej. Świat wirtualny jest miejscem nie tylko realizacji ludzkiej aktywności na wielu polach, ale także nawiązywania i utrzymywania relacji przez młodych ludzi. Obce sobie osoby wchodzą tam w różne interakcje - od bardzo incydentalnych po bliskie, a nawet intymne.

W artykule analizowane są następujące zagadnienia:

1. Dorastanie w epoce cyfrowej-czyli o pokoleniu Y i Z.

2. Uwarunkowania tworzenia relacji w okresie dorastania.

3. Komunikacja w świecie wirtualnym czynnikiem determinującym relacje młodzieży.

4. Świat wirtualny jako miejsce inicjacji bliższych relacji-przyjacielskich, partnerskich, intymnych.

\section{Słowa kluczowe:}

\section{młodzież}

pokolenie Y i Z

dorastanie

relacje

komunikacja

świat wirtualny 


\section{Virtual world as a place \\ to make and maintain \\ relationships by young people}

DOI: $10.47050 / 65591777.68-89$

Anna Andrzejewska

The space of human functioning undergoes constant changes, which are a natural process. Recent years have been the dynamic development of the digital space. The virtual word is not only a place of human activity in many areas, but also a place for establishing and maintaining relationships by young people. It is a meeting place for strangers who interact with each other, from very incidental ones, sometimes to those close and even intimate ones.

The following issues were discussed in the publication:

1. Growing up in the digital era - that is, about the $Y$ and $Z$ generation.

2. Conditions for creating relationships during adolescence.

3. Communication in the virtual world as a factor determining the relationships of young people.

4. The virtual world is the place of initiation of closer relations - friendly, partner and intimate.

\section{Keywords:}

youth

generation $\mathrm{Y}$ and $\mathrm{Z}$

adolescence

relationships

communication

virtual world 


\section{Wprowadzenie}

Rozpoczynając analizę problematyki związanej z nawiązywaniem i utrzymywaniem relacji przez młodzież w świecie wirtualnym, chciałabym przytoczyć słowa Józefa Bednarka: „świat wirtualny, z jednej strony, otwiera przed jego użytkownikiem olbrzymie możliwości-daje mu dostęp do zasobów na całym świecie, sprowadza odległość do roli nieistotnego czynnika, daje mu wolność, jakiej nie zaznaje w życiu codziennym. Jednak z drugiej strony nakłada ogromne ograniczenia. Potrzeba wielkiej wyobraźni, żeby żyć samym słowem i obrazem [...]. Wirtualny świat jest atrakcyjny, daleko odbiegający od rzeczywistości, fascynujący, pociąga swą niezwykłością i tym właśnie przyciąga wielu ludzi. Życie w wirtualnej wspólnocie pozwala wielu osobom na przezwyciężenie alienacji, samotności i izolacji" (Bednarek 2014, s. 23). Biorąc pod uwagę - typowy dla współczesności - prymat świata wirtualnego nad realnym jako miejsca aktywności młodzieży, problematyka ta nabiera coraz większego znaczenia.

\section{Dorastanie w epoce cyfrowej - czyli o pokoleniu Y i Z}

Pokolenie sieci utożsamiane jest $\mathrm{z}$ generacją $\mathrm{Y}$ - osobami urodzonymi w latach 1980-2000. Bywa określane jako "pokolenie millennium", "generacja globalna" czy "generacja multimedialna", mówi się o nich "luzacy", "generacja MTV", "cyfrowe dzieci wolnego rynku” czy „pokolenie klapek i iPadów" (Kubacka-Jasiecka, Passowicz 2014, s. 175) albo "generacja poszukująca”, "generacja net", „generacja why” czy "pokolenie IKEA". Osoby z pokolenia $Y$ to następcy reprezentantów pokolenia X (Bergh, Behrer 2012, s. 21-22). Telewizor, który dominował przez dziesięciolecia w wielu domach, został zastąpiony przez komputer, do którego podłączony jest internet. Jak twierdzi Edwin Bendyk: "sieć, której wcieleniami są zarówno internet, jak telefony komórkowe, jest w nowoczesnym świecie czymś równie oczywistym, jak powietrze i woda" (Bendyk 2004, s. 16). Pokolenie sieci jest pierwszym, które dorastało $w$ tej przestrzeni cyfrowej.

Generacja Y jest jedną z największych grup demograficznych. Jak dowodzi Josh McDowell, przedstawiciele tej grupy "są prawdopodobnie najbogatszym, najliczniejszym, najlepiej wykształconym i najsprawniejszym fizycznie pokoleniem w historii" (McDowell 2000, s. 16). „Prawdziwe porozumienie łączy ich tylko z rówieśnikami, z którymi wiąże ich jedność znaczeń i wartości kultury młodzieżowej, jej symbole (memy) 
budujące wspólnotową tożsamość. Przywiązują dużą wagę do przyjaźni, nawiązywania głębokich relacji o charakterze pozainstytucjonalnym - można mówić o «pokoleniu jakości, a nie ilości» w relacjach towarzyskich. Uważają się za indywidualistów i podkreślają swoją odrębność od innych ludzi. Lubią zwracać na siebie uwagę i popisywać się, nie zawsze przestrzegając intymności i naruszając prywatność innych, co uważa się za typowe dla «pokolenia reality show». W zasadzie unikają angażowania się w relacje z szerszym otoczeniem - stronią od działalności obywatelskiej, wspólnotowej, uciekają od zobowiązań wobec władzy i polityki. Równocześnie na poziomie deklaracji nie wykluczają możliwości głębszego osobistego zaangażowania w wybrane problemy społeczne" (Kubacka-Jasiecka, Passowicz 2014, s. 176).

Ludzie ci już teraz odgrywają i będą odgrywali w przyszłości kluczowe role w sferze kulturowej, biznesowej, socjalnej, ekonomicznej i politycznej. Pokolenie to jest mocno związane z technologiami informacyjno-komunikacyjnymi. Sposób, w jaki nawiązują znajomości, prowadzą życie towarzyskie, robią zakupy, jest ściśle związany z czasem, w którym się wychowali. Dlatego właśnie nazywani są „dziećmi rewolucji technologicznej" (Bergh, Behrer 2012, s. 20).

Dorastanie przedstawicieli pokolenia $Y$ w epoce cyfrowej miało ogromny wpływ na ich sposób myślenia. Powszechność technologii postawiła przed nimi duże wyzwania, związane szczególnie z nadmiarem informacji, które napływają ze wszystkich stron. Trudno zachować równowagę między dwiema rzeczywistościami: realną i wirtualną. Faktem jest, że doskonale radzą sobie z tymi aspektami: „Wydaje się, że nowinki techniczne nigdy im się nie przejedzą, a ich talent do wszystkiego, co cyfrowe jest zadziwiający" (Tapsott 2010, s. 51). Współcześnie ludzie nie korzystają już z bezpośredniego doświadczania rzeczywistości, wszystko dociera do nich przez media. Coraz więcej aktywności przenosi się do świata wirtualnego. „Realne jest to, co się dzieje na ekranie telewizora lub komputera” (tamże, s. 51). „Dla niektórych osób życie wirtualne jest tak pociągające, iż staje się ono życiem podstawowym. W cyberprzestrzeni tworzą swój własny, zamknięty świat - ograniczony do najbliższej przestrzeni życiowej, składającej się z kuchni, łóżka i komputera. Kiedy są z dala od niej, czują się źle, a czas spędzony w inny sposób uznają za stracony" (Andrzejewska 2012, s. 171).

Świat wirtualny umożliwia dowolne, zależne od potrzeb tworzenie wizerunku. Pozwala ukryć to, czego użytkownik nie chce pokazać na 
portalach społecznościowych (wad, kompleksów, problemów), a jednocześnie ułatwia zaprezentowanie i uwypuklenie zalet oraz mocnych stron. Bywa tak, że osoby nieśmiałe w świecie rzeczywistym okazują się $w$ sieci rozmowne i towarzyskie, a wiele $z$ nich popełnia drobne oszustwa z powodu chęci wybielenia siebie i ukrycia swoich braków (Trejderowski 2013, s. 61-62).

Jak twierdzi Józef Bednarek: „dla wielu ludzi cyberprzestrzeń stała się już częścią codzienności. Jesteśmy w cyberprzestrzeni, kiedy czytamy elektroniczną korespondencję albo gdy za pomocą sieci komputerowej rezerwujemy bilety lotnicze. W cyberprzestrzeni możemy rozmawiać, wymieniać poglądy, tworzyć wymyśloną przez siebie postać. Mamy też możliwość budowania nowego rodzaju społeczności, wirtualnych społeczności, do których przynależymy razem z ludźmi z różnych zakątków świata" (Bednarek 2014, s. 22). Nie do podważenia jest fakt, że komunikacja wymaga coraz mniej czasu, większość życiowych procesów organizuje się więc wokół sieci.

Przedstawiciel pokolenia Y jest aktywny, podejmuje wiele działań na rzecz innych ludzi, ale potrafi także działać z pobudek egoistycznych. Funkcjonuje jak komputer - natychmiastowo. Jest przyzwyczajony do szybkich reakcji, dlatego po wpisaniu określonej frazy w wyszukiwarce internetowej odpowiedź chce uzyskać natychmiast i tego samego oczekuje w życiu realnym. Każde działanie nakierowane jest od razu na odzew ze strony innych, niekiedy nawet zbyt długie oczekiwanie jest przyczyną frustracji (Bendyk 2004, s. 30). To sprawia, że osoby generacji Y szybko się nudzą, oczekują nagrody bezpośrednio po osiągnięciu rezultatu. Odczuwają ogromną potrzebę prędkości, chcą czerpać z życia pełnymi garściami. Doskonale wiedzą, że dzisiejszy świat daje im nieograniczone możliwości. Jednak "dla pokolenia $Y$ - w przeciwieństwie do poprzednich pokoleń - praca ani kariera nie są w życiu najważniejsze. Istotnymi wartościami są natomiast: samorozwój, świadomość społeczno-obywatelska oraz dobre relacje z otoczeniem (z rodzicami i przyjaciółmi)" (Bergh, Behrer 2012, s. 8).

Pojęciem, które jest ważne dla generacji Y, i z którym utożsamiają się jej przedstawiciele, jest wolność. Rozumieją je zarówno jako wolność w działaniach, jak i jako możliwość nierobienia niczego. Chcą mieć wybór w każdym aspekcie swojego funkcjonowania. Decydują, czy są aktywni w dzień, czy w nocy, żyją marzeniami, a zarazem chcą być efektywni. „Wolność internetu i możliwość wyrażania opinii w sieci jest 
równie ważna, jak dla poprzednich pokoleń ruch «Solidarność», który był symbolem walki o swobodę wypowiedzi" (Bergh, Behrer 2012, s. 8). Nowoczesna technika pozwala przełamywać dotychczasowe schematy. Młodzi ludzie dążą do swobody w wyborze pracy, drogi życiowej, miejsca zamieszkania czy wyrażania siebie - „bez możliwości wyboru nie mogą żyć, jak bez powietrza" (Tapsott 2010, s. 85).

W pokoleniu Y można zaobserwować przesunięcie wieku wkraczania w dorosłość (do granicy około trzydziestu lat). Przedstawiciele tej generacji przedłużają okres nauki, odkładają moment zawierania związków małżeńskich, a także dłużej pozostają na utrzymaniu rodziców, chcąc możliwie najdłużej żyć pełnią życia i przedłużyć swoją młodość.

Jedną z przyczyn tego stanu rzeczy jest sposób ich wychowania. Większość przedstawicieli tego pokolenia dorastała w dobrobycie, a ich rodzice byli bardziej dojrzali i wykształceni. Dorośli brali pod uwagę zdanie swoich dzieci i pozwalali im na podejmowanie wielu decyzji. Rodzice poświęcali im również dużo więcej uwagi niż tym z poprzednich pokoleń, a budując dla nich perspektywy na przyszłość, sprawili, że stały się one najważniejszymi członkami rodziny. Miejsce surowej dyscypliny zastąpiła wzajemna akceptacja i tolerancja.

W dzisiejszych czasach rodzice są chętni do podejmowania rozmów i negocjacji, starając się uniknąć jakichkolwiek konfliktów, objawów buntu czy oporu. Obecnie aż dwie trzecie z nich pyta swoje dziecko o zdanie podczas wyboru miejsca spędzenia wspólnych wakacji (Bergh, Behrer 2012, s. 22-27). Taki model wychowania sprawia, że przedstawiciele generacji sieci są bardziej cyniczni i krytyczni, a także trudniej ich zaskoczyć.

Pokolenie Y nie zaznało takiego dzieciństwa jak poprzednie pokolenia. Ich wolny czas zdominowała aktywność w sieci, stąd bardzo często nazywani są także pokoleniem „wujka Google i cioci Wiki”. Gry komputerowe i kilkanaście kanałów dziecięcych w telewizji do wyboru spowodowały, że dzieci nie musiały wytężać swojego umysłu na twórcze zabawy.

Obecnie mamy do czynienia z generacją Z, zwaną inaczej Tweens lub pokoleniem c-connected - „podłączeni do sieci” (Zajada 2014, s. 61). Generacja Z to osoby urodzone po 1990 r. (niektórzy eksperci wyznaczają jako graniczny 1995 r.). Czasem określa się ich także jako cyfrowych tubylców (digital natives), generację M (multitasking), generację C (connected generation) czy net generation. Są dziećmi dzisiejszych 
czterdziestolatków, czyli tych osób, które miały możliwość skorzystania z szans, jakie przyniosła im transformacja ustrojowa. Dzięki temu przedstawiciele pokolenia Z uzyskali dobre wykształcenie, są zamożni, otwarci na świat i mają szansę na sukces zawodowy. Jest to również w dużej mierze pokolenie jedynaków - egocentryków. Przyzwyczajeni są do łatwego, przyjemnego życia. Trudniej nawiązują trwałe więzi, a szczególną ich cechą jest coraz większy brak empatii.

To osoby obecnie przeżywające swoje młodzieńcze lata. Ich okres dorastania przypada na czas największego rozkwitu nowych technologii informacyjno-komunikacyjnych. Urodziły się w czasach niestabilnych gospodarczo, pełnych niebezpieczeństw (między innymi zamachy terrorystyczne, przemoc w społeczeństwie, uzależnienia, cyberprzestępczość). Mimo świadomości tych niebezpieczeństw pokolenie Z wykazuje optymizm, idealizm, różnorodność, ambicje, kreatywność i innowacyjność. Swoje poglądy i idee czerpie z wielu źródeł. Pewne cechy przyswaja od poprzedniej generacji, a inne powiela ze starszych źródeł. Potrafi myśleć o problemach globalnych, ale także o globalnych szansach.

Jest to pokolenie, które ma wiele możliwości, jednocześnie jest to najbardziej podzielona generacja pod względem kulturowym, ekonomicznym, ale także mentalnym, od czasów zakończenia drugiej wojny światowej. Jak podkreślają Dorota Kubacka-Jasiecka i Piotr Passowicz, jest to „pokolenie wychowane przez internet, w świecie nierzeczywistych złudzeń, [które] w realnej rzeczywistości zostaje zmuszone do konfrontacji z otwartymi podziałami finansowymi, majątkowymi, prestiżowymi, wreszcie politycznymi współczesnego społeczeństwa" (Kubacka-Jasiecka, Passowicz 2014, s. 175). Urodzeni w czasach rozkwitu internetu oraz nowych technologii, od małego są z nimi zapoznani, dzięki czemu sprawnie potrafią się posługiwać mediami cyfrowymi. Pokolenie to „ma wysoki poziom kompetencji związany z wykorzystaniem technologii" (Zajada 2014, s. 61). Jego przedstawiciele wierzą, że mogą wpłynąć na przyszłość i wprowadzić do niej zmiany. Biegłe posługiwanie się przez nich technologiami informacyjno-komunikacyjnymi wpłynęło także na ich życie realne. Przedstawiciele tej generacji „przenieśli" do świata realnego określenia używane wcześniej w mediach cyfrowych. Podczas rozmów używają skrótów typu "CU”, „G2g” lub "4U", przejawiają ponadto silną potrzebę bycia akceptowanymi przez 
rówieśników i jedności z grupą. Można zauważyć, że rówieśnicy mają duży wpływ na wzajemne kształtowanie postaw i zachowań.

Nowości technologiczne są nieodłączną częścią życia młodych ludzi, którzy mają zdolność doskonałego poruszania się w wirtualnym świecie. Nieodzownym ich atrybutem są różne gadżety elektroniczne. Nie znają świata bez smartfonów, tabletów, internetu. W związku z tym, że urodzili się w świecie cyfrowym, nie pamiętają czasów telewizorów bez pilota czy telefonów niemających ekranów dotykowych. Osoby dorosłe stopniowo wkraczały do cyfrowego świata, pokolenie Z wychowało się w tym środowisku.

Pokolenie $Z$ realne życie i kontakty twarzą $w$ twarz zastępuje kontaktami w wirtualnym świecie. Można stwierdzić, że dla jego przedstawicieli liczy się przede wszystkim to, co jest online. Żyją i przebywają w społeczności wirtualnej, w których funkcjonują ludzie o podobnych pasjach i zainteresowaniach. Nie boją się pracy na odległość, obsługi skomplikowanych maszyn i programów informatycznych. Dla nich rzeczywistość nie musi być namacalna. Mogą wykonywać wiele czynności jednocześnie - uczą się, słuchając muzyki, wysyłając i odbierając esemesy, patrząc w ekran komputera. Trudno skupić się im na jednej czynności, ich uwaga jest rozproszona, a ich świat to kompilacja setek fragmentów - puzzli, które są w stanie bardzo sprawnie złożyć. Poruszają się w gąszczu różnorodnych aplikacji, są bombardowani wielością przekazów. Świat cyfrowy traktują jak powietrze, którym oddychają natychmiast po przebudzeniu.

Korzystanie z zasobów cyfrowego świata może przynieść oprócz korzyści także wiele zagrożeń, $w$ tym nieuświadomionych i jeszcze nienazwanych, szczególnie w zakresie podejmowanych wyborów. Obawą napawa fakt zacierania się granicy między tym, co realne, a tym, co nierzeczywiste. Bronisław Siemienicki podkreśla fakt, że „zanurzenie się współczesnej cywilizacji w mediach powoduje, że występuje coraz silniejszy związek naszych zachowań z wirtualnym światem" (Siemieniecki 2002 , s. 43). Analizując przebywanie młodzieży w przestrzeni cyfrowej, należy zatem zgodzić się z poglądem Marty Wrońskiej, która konstatuje: „niestety nieustanne przebywanie w przestrzeni medialnej powoduje, że [młodzi ludzie] często wyrzucają ze swego harmonogramu dziennego spotkania face to face. Zaczynają wchodzić w różnorodne światy wirtualne, gdzie ich kontakty nabierają pozorności, są niewidoczne, aprzestrzenne i aczasowe. Zaciera się granica między światami 
realnym i wirtualnym, a ich rzeczywista przestrzeń znajduje się w wirtualnym wymiarze. Oddalając się od realności, zaczynają być zagrożeni immersją - zanurzeniem w świat, z którego trudno się wydostać, tym bardziej, że jest to miejsce, gdzie mogą konstruować własne życie poza kontrolą dorosłych" (Wrońska 2015, s. 71). Można także dodać, że prowadzi to do braku nawiązywania głębszych więzi społecznych w świecie rzeczywistym. Maciej Tanaś z kolei zwraca uwagę na fakt, że "świat mediów pozostawia głęboki ślad w umyśle dziecka. Współczesna generacja wyrasta w środowisku mediów w przeciwieństwie do pokoleń minionych. Ten ślad jest trwały, media bowiem nie tylko przekazują informacje, lecz rodzą emocje, kształtując sferę wyobraźni, budzą pragnienia i marzenia, mieszając hierarchie wartości i realizując zadania tylko niekiedy zbieżne z oczekiwaniami pedagogów i nauczycieli" (Tanaś 2007b, s. 198). Dlatego duże znaczenie przypisuje się dzisiaj nie tylko wychowaniu za pomocą mediów, ale także wychowaniu do mediów, które powinno skutkować, jak dalej podkreśla autor: „budowaniem adekwatnego stosunku człowieka do świata mediów i rzeczywistości wirtualnej, rozumieniem ich miejsca i relacji wobec świata rzeczywistego, kształtowaniem przekonań i postaw, układu i hierarchii wartości, celu życia, relacji z innymi ludźmi i humanistycznego stosunku do nich" (tamże, s. 202).

Na tle tych rozważań zasadny wydaje się pogląd Anthony'ego Giddensa: „nowoczesność w sposób nieunikniony globalizuje, a destabilizujące następstwa tego zjawiska łączą się z kolistością jego refleksyjnego charakteru, tworząc uniwersum zdarzeń, w którym ryzyko i zagrożenie nabiera nowego charakteru" (Giddens 2008, s. 125). Janusz Morbitzer z kolei zwraca uwagę, że "każda technologia, ale też kultura, idea, człowiek, aby moc ujawnić pełnię swoich możliwości musi trafić do odpowiednio przygotowanego środowiska. Problem polega na tym, że rozwój technologii zawsze wyprzedza rozwój kulturowy i społeczny" (Morbitzer 2013 , s. 11). W obliczu tych refleksji nasuwa się kluczowe pytanie: w jakim stopniu przedstawiciele pokolenia $Z$ zostali przygotowani przez poprzednie generacje, aby korzystać $z$ dobrodziejstw nowych technologii w sposób dający pożytek im samym, ale także ich następcom?

Pokolenie Z dopiero wchodzi w dorosłe życie i na rynek pracy, dlatego też badania na temat oczekiwań jego reprezentantów wobec życia i zatrudnienia są w początkowej fazie. Już teraz mówi się jednak, że ta generacja będzie miała duży wpływ na otaczający świat, zrewolucjo- 
nizuje i unowocześni obecną rzeczywistość, a być może zmieni ją na niespotykaną dotąd skalę.

\section{Uwarunkowania tworzenia relacji w okresie dorastania}

W okresie dorastania bardzo ważne są relacje z innymi ludźmi, zwłaszcza z rówieśnikami. Kontakty społeczne i dobre stosunki z otoczeniem umożliwiają młodym ludziom właściwe funkcjonowanie i radzenie sobie ze stresem, zapobiegają depresji i innym zaburzeniom natury psychicznej. Posiadanie przyjaciół daje poczucie szczęścia, a także świadomość, że można liczyć na wsparcie w sytuacjach kryzysowych. Młodzi ludzie wykazują potrzebę akceptacji i przynależności społecznej. Zaspokojenie tej potrzeby pozwala im wzmacniać poczucie własnej wartości oraz nabywać i ćwiczyć różne kompetencje społeczne. Z tego powodu na ogół chętnie i łatwo nawiązują znajomości oraz tworzą więzi. Aby jednak między ludźmi zaistniała relacja zapewniająca szerokie możliwości działania, musi wystąpić interakcja z innymi osobami, wsparta świadomością obowiązywania norm i zasad oraz znajomością własnego miejsca w społeczności.

W okresie dorastania, który jest czasem szczególnym i złożonym, w człowieku dokonuje się wiele gwałtownych przemian. Wytwarzają się nowe wzorce relacji, bardzo szybko wzrasta liczba doświadczeń osobistych i społecznych, następuje również rozwój kompetencji. Występują także ogromne zmiany związane z budowaniem poczucia tożsamości osobistej i społecznej. Dorastanie to ostatni etap procesu intensywnego rozwoju. Po jego zakończeniu człowiek staje się dorosły, dojrzały, samodzielny, jego życie (pod względem biologicznym i psychicznym) nabiera cech względnej stabilizacji.

Bardzo często młodzi ludzie mają obawy przed oceną zewnętrzną i krytyką, boją się zabrać głos w danej sprawie, wycofują się. Barierami w relacjach z innymi są między innymi kompleksy, wstyd, złe doświadczenia lub negatywne nastawienie. Z pomocą przychodzi im świat cyfrowy, w którym przez długie godziny przebywają i który pozwala przekraczać te ograniczenia, dzięki czemu kontakty wirtualne są o wiele łatwiejsze. Za pośrednictwem internetu młode osoby mogą "manipulować wrażeniami” - tworzyć swoje „wybiórcze ja”. Tak dzieje się szczególnie wśród młodych użytkowników portali społecznościowych, a jak wskazuje Adam Andrzejewski: „sposób, w jaki dokonujemy na nich autoprezentacji, rodzaje treści, które udostępniamy, 
a w szczególności to, jak jesteśmy oceniani przez innych użytkowników, którzy niekoniecznie muszą być naszymi znajomymi z realnego życia, ma szczególny wpływ na fundamentalne segmenty tożsamości" (Andrzejewski 2018a, s. 22).

W epoce globalnego dostępu do technologii informacyjno-komunikacyjnych nastąpiło szybkie rozprzestrzenianie się kontaktów międzyludzkich, które tworzą siatkę różnych powiązań. Rozwój technologii, zwłaszcza internetu, w ogromnym stopniu wpłynął na zmediatyzowanie komunikacji międzyludzkiej, a tym samym na tworzenie $w$ ten sposób relacji i więzi społecznych. Sieć jest bowiem formą mediów, których istotą jest komunikacja, a treść stanowi informacja" (Goban-Klas 2005, s. 2). Należy jednak podkreślić, że świat wirtualny nie tylko ułatwia komunikację międzyludzką, ale także sprzyja tworzeniu relacji (znajomość, koleżeństwo, przyjaźń czy nawet miłość). Janusz Morbitzer twierdzi, że współczesny globalny świat, w którym występuje mnóstwo rozmaitych interakcji i współzależności, jest coraz bardziej skomplikowany i coraz trudniejszy do zrozumienia (Morbitzer 2014, s. 193-194). W tej przestrzeni prawdy i fałszu ludzie poszukują bliskości, angażując się $w$ relacje incydentalne, ale także bardzo intymne.

Zdaniem Macieja Tanasia: „niezależnie od kierunków i sposobów analizy współczesnych technologii informacyjno-komunikacyjnych pojawia się ich wymiar społeczny i pedagogiczny. Refleksja nad konsekwencjami rozwoju technologicznego i konstruowanej cywilizacji medialnej nie może bagatelizować jej twórcy oraz zbyt często manipulowanego i niemal bezbronnego konsumenta. Media cyfrowe stały się bowiem czynnikiem determinującym nie tylko przeobrażenia społeczne, cywilizacyjne i kulturowe, ale też (pośrednio bądź bezpośrednio) los każdego niemal człowieka, w tym - co szczególnie ważne dla pedagoga - styl życia, relacje społeczne, typy aktywności poznawczej, twórczej, a nawet ludycznej dzieci i młodzieży" (Tanaś 2015, s. 11). Sylwia Galanciak podkreśla zaś, że „życie w dynamicznie przeobrażającym się świecie sprawia, że trudno dostrzec ciągłość i logikę zachodzących w nim zmian, które z perspektywy uczestnika mogą wydawać się raczej stanem radykalnego zerwania z dotychczasowym porządkiem, zasługującym w pełni na miano rewolucji" (Galanciak 2015, s. 247). Fundamentalne zatem dla pedagogów staje się pytanie, które stawia Bogusław Śliwerski: „Jak przeżywany jest świat wirtualny i co z tego świata «nosi» w sobie nasz wychowanek?" (Śliwerski 2016, s. 30). 


\section{Komunikacja w świecie wirtualnym czynnikiem determinującym relacje młodzieży}

Analizując problematykę komunikacji w świecie wirtualnym i jej uwarunkowania w zakresie tworzenia relacji przez młodzież, należy zwrócić uwagę, że "rozwój technologii informacyjno-komunikacyjnych poszerzył pole możliwych kontaktów osobistych i dostarczył atrakcyjne narzędzie komunikacji, umożliwiające zawieranie nowych kontaktów $\mathrm{i}$ ich podtrzymywanie bez respektowania granic terytorialnych, a nawet czasowych" (Tanaś 2016a, s. 6). Podążając za tą myślą, Adam Andrzejewski stwierdza, że „wraz z rozwojem współczesnych technologii informacyjnych, sieć staje się medium zaspokajającym potrzeby komunikacji międzyludzkiej. Maile, czaty, komunikatory, blogi, fora dyskusyjne i serwisy społecznościowe stanowią tętniące życiem wirtualne platformy tworzenia więzi grupowych, wymiany zdań, myśli i emocji. W obecnych czasach sieć internetowa pozwala swoim użytkownikom na prowadzenie dyskusji na prawie każdy temat. Internauci z całego świata uczestnicząc $w$ różnorodnych grupach i tematycznych forach dyskusyjnych wymieniają się wiedzą, informacjami, poglądami oraz poradami w zakresie treści znajdujących się w płaszczyźnie ich zainteresowań" (Andrzejewski 2018b, s. 183).

Komunikacja międzyludzka za pośrednictwem internetu przechodzi duże przeobrażenia. Podzielić ją można na „pośrednią i bezpośrednią w zależności od tego, czy odbywa się ona «twarzą w twarz» czy też przy pomocy mediów" (Andrzejewska 2012, s. 295). „W przypadku komunikacji bezpośredniej główne źródło informacji stanowią sygnały niewerbalne, a więc: wyraz twarzy, ton głosu, postawa, ruchy rąk, sposób patrzenia itp." (Kacprzak, Leppert 2013, s. 22). Na ich podstawie ludzie odbierają komunikaty wysyłane przez drugą osobę i łączą je lub weryfikują z komunikatami werbalnymi. Komunikaty pośrednie są trudniejsze do odczytania - między dwojgiem ludzi pojawia się dodatkowa bariera. "Źródłem informacji o drugim człowieku jest nie tylko rozmowa z nim, ale także sposób, w jaki formułuje swoje wypowiedzi" (tamże, s. 23).

Współcześnie komunikacja face to face ustępuje miejsca komunikacji interface to interface (Szpunar 2007, s. 96). W pierwszym z wymienionych typów komunikacji widoczne jest nastawienie na bliski kontakt rozmówców, bezpośrednią interakcję, na którą - poza słowami - składają się gesty, postawa ciała, mimika, ton głosu, nastawienie na partnera w rozmowie. Niewerbalne komunikaty często wyrażają wię- 
cej niż wypowiadane słowa, gdyż niosą ze sobą naturalny dla każdego człowieka ładunek emocjonalny.

Drugi typ komunikacji obdziera rozmówców z ich naturalności, sam człowiek staje się zbędny, na pierwszy plan wysuwa się interakcja z maszyną (Wasylewicz 2012, s. 121). Interakcję w świecie wirtualnym ułatwiają emotikony, wielkość czcionki, opisywanie swoich ruchów, zachowań, reakcji. Coraz bardziej popularne staje się komunikowanie z wykorzystaniem kamer internetowych. Rozmówcy widzą się nawzajem, ale choć nie mogą się dotknąć, mogą zaobserwować reakcje drugiej osoby i rozmawiać z nią "twarzą w twarz". „Brak komunikacji niewerbalnej ma swoje pozytywne strony, ponieważ mniej znaczące są wskazówki dotyczące wyglądu fizycznego, statusu, płci. Uczestnicy komunikacji online rzadziej popadają w schematyczne oceny czy atrybucje, dotyczące zachowań innych ludzi" (Branicki 2013, s. 168). Dlatego nowo poznana osoba $w$ świecie wirtualnym przede wszystkim oceniana jest za częstotliwość przebywania w sieci, częstość komunikowania się, sposób wypowiedzi, poglądy, zainteresowania, a nie za wgląd zewnętrzny.

Dużą zaletą wirtualnej komunikacji jest łatwość nawiązywania kontaktów. Styl życia współczesnych ludzi (w tym także młodzieży) związany jest z pośpiechem, brakiem czasu, niepewnością jutra i wieloma zahamowaniami. Coraz trudniej jest nawiązać relację z drugą osobą, a tym bardziej ją utrzymać. Świat wirtualny znosi te bariery, pozwalając na poszukiwanie i poznawanie ludzi w dowolnym momencie. Może się to odbywać w drodze do szkoły, podczas przerwy w pracy lub odpoczynku czy w rano, tuż po przebudzeniu.

Warto przybliżyć działanie mechanizmów umożliwiających współcześnie tak szerokie kontakty społeczne i przyjrzeć się dokładniej charakterystycznym elementom komunikacji wirtualnej. Bogdan Zeler i Urszula Żydek-Bednarczuk wymieniają następujące atrybuty e-komunikacji:

$\rightarrow$ Przestrzeń wirtualna nie ma ograniczeń. Interakcje w sieci nie są ograniczone ani czasowo, ani geograficznie, co daje możliwość porozumiewania się i podtrzymywania znajomości z ludźmi z całego świata.

$\rightarrow$ Działania synchroniczne lub asynchroniczne. Komunikacja wirtualna nie ma ograniczeń czasowych, co pozwala na nawiązanie porozumienia w czasie rzeczywistym, natychmiastowo (synchronicznie). Możliwe jest jednak również przesyłanie takich komu- 
nikatów, które odbiorca przeczyta po pewnym czasie - strony dialogu nie muszą być jednocześnie obecne w przebiegu rozmowy (asynchronicznie).

$\rightarrow$ Komunikacja wirtualna jest pozbawiona cielesności. Głównym środkiem przekazu w sieci jest tekst, a także dźwięk, obraz. Coraz częściej wykorzystywane są również kamery, pozwalające jednocześnie widzieć i słyszeć rozmówcę, umożliwiające porozumienie przy użyciu gestów, mimiki, układu ciała. Wszystkie te działania w procesie komunikacji wirtualnej są jednak pozbawione kontaktu fizycznego, możliwego tylko podczas komunikacji „twarzą w twarz".

$\rightarrow$ Komunikacja wirtualna zapewnia anonimowość. W sieci bardzo często użytkownicy tworzą postać, jaką chcą być, dzięki możliwości zatajenia prawdziwych informacji o sobie. Taka sytuacja może prowadzić do fałszowania własnej tożsamości, ale także podszywania się pod inną osobę.

$\rightarrow$ Sieć umożliwia zmianę tożsamości. Użytkownicy tworzący swoją tożsamość mogą łatwo przekroczyć granicę, za którą pojawiają się zaburzenia osobowości. Wynikają one z ponadnormatywnego zaangażowania $w$ tworzenie innego obrazu siebie, niż jest w rzeczywistości, na potrzeby świata wirtualnego i z nadmiernego zaangażowania w kontakty w sieci (Zeler, Żydek-Bednarczuk 2009, s. 86-87).

Anna Słysz i Beata Arcimowicz podkreślają, że wirtualne kontakty zaspokajają potrzebę wsparcia (Słysz, Arcimowicz 2009, s. 30), niezbędnego każdemu człowiekowi w różnych momentach życia. Internet daje ku temu wiele możliwości.

W literaturze przedmiotu wyróżnia się trzy podstawowe rodzaje wsparcia: emocjonalne, informacyjne i instrumentalne. (Sęk 2004, s. 11).

Wsparcie emocjonalne można uzyskać głównie na forach poświęconych danym tematom (na przykład chorobom). Oprócz przekazywania słów otuchy użytkownicy nawiązują prywatne relacje, prowadzą rozmowy, podczas których mogą zwierzyć się ze swoich problemów. Wsparciu temu nie towarzyszą jednak niewerbalne gesty, takie jak przytulenie, potrzymanie za rękę, bardzo pomocne w trudnych chwilach. Są one nieraz zastępowane emotikonami lub słowami. Osoby szukające emocjonalnego wsparcia w sieci często nie mają odwagi przy- 
znać się najbliższym osobom w świecie rzeczywistym, że potrzebują pomocy, rozmowy, wysłuchania - łatwiej im się otworzyć przed kimś, kogo nie widzą, a mogą sobie jedynie wyobrażać, kim jest. Udzielanie emocjonalnego wsparcia łączy użytkowników internetu. Podtrzymują oni kontakty ze względu na okazane sobie nawzajem zainteresowanie problemami i chęć dawania otuchy. $Z$ czasem niektóre takie relacje można nazwać przyjaźnią.

Wsparcie informacyjne polega na wymianie takich informacji, które są pomocne w trudnej sytuacji i stanowią pomysł na jej rozwiązanie. Źródłem wsparcia informacyjnego jest osoba, która rozwiązała już problemową sytuację zbliżoną do tej, w jakiej znalazła się druga strona relacji. Internet daje użytkownikom szerokie możliwości w zakresie wzajemnego wsparcia informacyjnego. Niemal na wszystkie problemy dnia codziennego można znaleźć receptę w sieci, podobnie jak opinie o wszelkich produktach i usługach. Brak granic czasowych i geograficznych umożliwia znalezienie osób znajdujących się w podobnej sytuacji, nawiązanie z nimi kontaktu i podzielenie się sposobami poradzenia sobie z danym kłopotem. Trzeba pamiętać jednak, że informacje rozpowszechniane w internecie nie zawsze są zgodne z rzeczywistością, wystawiane opinie mogą być kryptoreklamą lub subiektywnym poglądem, wyrażonym na podstawie osobistych doświadczeń niezwiązanych z problemem.

Wsparcie instrumentalne polega na podaniu gotowej instrukcji postępowania w konkretnej sytuacji. Użytkownik poszukuje porady, informacji w określonej sprawie, i pod tym kątem przegląda fora, sam zadaje na nich pytania, zapoznaje się ze stronami internetowymi o zbliżonej do problemu treści.

Poza potrzebą wsparcia wirtualne znajomości zaspokajają również inne potrzeby w zakresie kontaktu z ludźmi, uzyskania akceptacji i szacunku (Słysz, Arcimowicz 2009, s. 45). Można przyjąć, że interakcja, jaką umożliwia swoim użytkownikom sieć, jest tylko namiastką prawdziwego kontaktu. Obecnie, kiedy rozmowę zamieniamy na stukanie w klawiaturę, a emocje - na emotikony, wirtualne znajomości często nie zapewniają kontaktu z ludźmi, pochłaniając zaś czas i energię. Potrzeba akceptacji i szacunku zaspokajana przez internetowe znajomości bywa tylko złudzeniem, gdyż ludzie ukazują siebie takimi, jakimi chcą być widziani przez innych. Ważny $w$ tym zakresie jest pogląd wyrażony przez Adama Andrzejewskiego, który zwraca uwagę na fakt, że „specyficzne 
grupy dyskusyjne w internecie mogą oddziaływać na psychikę innych użytkowników w celu kształtowania $\mathrm{z}$ ich punktu widzenia wzorców zachowań" (Andrzejewski 2018b, s. 185). Dlatego, jak dodaje: „ważna staje się potrzeba szerokiego dyskursu nad problematyką forów internetowych o charakterze destrukcyjnym, których twórcami i użytkownikami stają się coraz częściej bardzo młodzi ludzie" (tamże).

\section{Świat wirtualny miejscem inicjowania bliższych relacji - przyjacielskich, partnerskich, intymnych}

Nawiązywanie i podtrzymywanie relacji społecznych w internecie w bardzo szybkim tempie zastępuje tradycyjne formy i miejsca zawierania i kontynuowania znajomości - osiedlowe place zabaw, spotkania ze znajomymi i rozmowy twarzą w twarz. Warto jednak wspomnieć, że niektóre $z$ wirtualnych relacji przeniesione do realnego świata mogą być początkiem przyjaźni i dalej rozwijać się już poza siecią. Relacje zawarte w cyfrowej rzeczywistości mogą być później budowane różnie - w zależności od uczestników interakcji mogą to być związki trwałe lub ulotne, zawierane szybko lub powoli.

W życiu większości ludzi najważniejszymi relacjami międzyludzkimi (oprócz rodzinnych) są relacje przyjacielskie i partnerskie. Każdy człowiek potrzebuje bliskiej osoby, na której może polegać niezależnie od czasu, miejsca i sytuacji. Jest to szczególnie istotne dla młodych osób. Nawiązanie przyjaźni przez internet stało się obecnie bardzo wygodne i łatwe. Wiele osób nie chce tracić czasu i energii na poszukiwanie osób podobnie do nich postrzegających świat. W takich sytuacjach przydatny jest internet - wystarczy włączyć komputer lub smartfon i przenieść się w miejsce (czat, komunikator, portal społecznościowe, forum dyskusyjne, blog), w którym można poznać przyszłego przyjaciela - partnera do rozmów, z którym można się bez obaw podzielić poglądami i z którym można porozmawiać o problemach.

Przyjaciel, z samej definicji, jest osobą bliską, która odgrywa ważną rolę w życiu człowieka. Jest powiernikiem, doradcą, wsparciem i kompanem w wielu sytuacjach życiowych. „Przyjaźń jest interakcją całkowicie dobrowolną, spontaniczną, subiektywnie odczuwalną i przeżywaną, która nie może być poddawana żadnym definicjom normatywnym ani też prawom logicznym. Dzieje się tak dlatego, że każdy związek dwóch osób określanych przyjaciółmi opiera się na jedynie im znanych zasa- 
dach, oczekiwaniach i płynącej z tego związku satysfakcji" (Szewczuk 1998, s. 498).

Przyjaźń zawierana w świecie realnym niejednokrotnie narażona jest na wiele przeciwności. Przyjaciele chcą ze sobą spędzać cały czas, co nie jest wcale proste. Relacje takie zależą od uwarunkowań zewnętrznych, często uczestniczą w nich osoby trzecie. Ma na nie wpływ również środowisko, w którym żyją uczestnicy relacji przyjacielskiej, i sposób, w jaki zostali wychowani. Z kolei „przyjaźń tworzona w cyberprzestrzeni ma charakter kompensacyjny dla osób, które z uwagi na blokady lękowe mają trudności w nawiązywaniu relacji przyjaźni w realności" (Branicki 2013, s. 168). Cyberprzestrzeń zapewnia im poczucie anonimowości, co z kolei przyczynia się do zwiększenia pewności siebie. Umożliwia również ukrycie tych elementów, których dana osoba się wstydzi. „Aby jednak ich [ludzi] kontakty stawały się pełniejsze, wirtualne spotkania często potrzebują realnego przedłużenia, «prawdziwego odpowiednika» umożliwiającego cielesne poznanie i kontakt niezapośredniczony" (Stachura 2006, s. 68). Dochodzi wtedy do dewirtualizacji znajomości, co rozumie się jako świadomą zamianę kontaktów w świecie wirtualnym na kontakty w świecie realnym (Barani 2009, s. 113). Przeniesienie kontaktów wirtualnych do świata realnego nie wyklucza kontynuowania relacji internetowej, niezaprzeczalnie jednak znajomość przeniesiona w świat rzeczywisty wchodzi na wyższy poziom - osoba spotkana "twarzą w twarz" jest bardziej prawdziwa, autentyczna, godna zaufania.

Kontakty najczęściej przenoszone do rzeczywistości wynikają z rodzaju relacji partnerskich. O ile przyjaźń na odległość jest akceptowalna, o tyle utrzymywanie związku jest trudne i zazwyczaj jest rozwiązaniem na krótki czas. Wynika to z faktu, że związki partnerskie opierają się na bliskości dwojga osób, a więc bezpośredni kontakt fizyczny ma na nie duży wpływ.

Młodzi ludzie, którym zależy na znalezieniu partnera, coraz częściej korzystają z portali randkowych. Jest to dobre rozwiązanie dla osób nieśmiałych, które w realnym świecie nie zdobyłby się na odwagę, by zaprosić przypadkowo spotkaną na ulicy osobę na kawę lub wspólny spacer. Bariera monitora sprawia również, że ludzie łatwiej i szybciej otwierają się przed innymi - czasem nawet nie zauważają, że zaczynają zwierzać się obcej osobie, o której w gruncie rzeczy nic nie wiedzą. Relacja taka przybiera wtedy formę intymnej rozmowy, opartej na po- 
lubieniu się i wzajemnym zaufaniu, czyli na warunkach koniecznych dla przetrwania znajomości (Kacprzak, Leppert 2013, s. 44). Kontakt ten może być bliższy w związku z tym, że z internetu korzysta się w zasadzie bez przerwy - po nadejściu nowej wiadomości od osoby poznanej w sieci natychmiast pojawia się powiadomienie, na które możemy błyskawicznie odpowiedzieć, zupełnie tak, jakbyśmy rozmawiali w czasie rzeczywistym. Wirtualna relacja może zamienić się $\mathrm{w}$ realną - nawet partnerską - na całe życie.

Osobom szukającym partnera życiowego często zależy na przeniesieniu znajomości do świata realnego. Dzięki temu możliwe jest poznanie drugiej osoby taką, jaka jest naprawdę, a nie taką, na jaką się kreuje. Można sprawdzić, czy między dwiema osobami zaistniała więź, czy pojawiły się między nimi jakieś uczucia. „Przyczynami aż tak szybkiego tempa wydarzeń mogą być: potrzeba przekonania się, czy pomiędzy partnerami «zaiskrzy», chęć jak najszybszego sprawdzenia kolejnych profili, $w$ razie gdyby znajomość $z$ danym partnerem miała się nie ułożyć, brak zaufania do informacji umieszczonych w profilu użytkownika albo chęć szybkiego sprawdzenia, kto tak naprawdę ukrywa się pod danym profilem" (Whitty, Carr 2007, s. 199-201). Dewirtualizacja takiej znajomości umożliwia przekonanie się, kim w rzeczywistości jest osoba poznana w sieci. Pozwala zaoszczędzić czas w sytuacji, gdy nawiązana relacja okazuje się jedynie wykreowanym w internecie tworem. Często jednak przeniesienie znajomości do świata rzeczywistego jest niemożliwe lub mało prawdopodobne, na przykład wtedy, gdy rozmówcy mieszkają na dwóch krańcach świata, są niesamodzielni albo niepewni siebie i boją się, że po spotkaniu "na żywo" nie będą już atrakcyjni czy interesujący dla drugiej strony.

Część osób w Polsce nadal z nieufnością podchodzi do związków zawieranych w internecie, ale wzrasta liczba osób, które wykorzystują internet do poszukiwania "drugiej połówki". Niektórzy bardzo długo noszą się z tą decyzją - wstydzą się zamieścić swoje zdjęcie na portalu randkowym, obawiając się braku akceptacji dla takiej znajomości ze strony rodziny czy bliskich. Sieć staje się jednak na tyle popularnym narzędziem poznawania nowych osób, że niebawem publiczne przyznanie się do faktu, że partnera czy partnerkę poznało się w sieci, nie będzie niczym zadziwiającym. Uwaga ta w mniejszym stopniu dotyczy nastolatków, którzy cyberprzestrzeń traktują jako naturalne środowisko poznawania nowych ludzi i wchodzenia z nimi w relacje partnerskie. 
Do poszukiwania życiowego partnera służą portale randkowe. „E-randki cieszą się taką samą popularnością wśród mieszkańców dużych miast, jak i na wsiach. Dzięki cyberprzestrzeni ludzie mają możliwość spotkania się z kim tylko zapragną, gdzie tylko chcą, o każdej porze dnia i nocy i w dowolnym miejscu. Ponadto internet zapewnia poczucie anonimowości, która pozbawia wielu oporów, daje poczucie bezpieczeństwa i ośmiela. W wirtualnej przestrzeni łatwiej zadać bezpośrednie pytanie, stawiać wymagania, czy flirtować. Łatwiej jest także powiedzieć: nie chcę się już z Tobą spotykać" (Witak [online], 8.10.2018). „Flirt w Internecie (cyberflirt), to specyficzna forma interakcji, którą należy rozważać w oderwaniu od flirtu w świecie realnym. Skupiając się na samej wymianie komunikatów tekstowych, trzeba przyznać, że nie występuje w nich żaden z sygnałów charakterystycznych dla flirtu w świecie realnym" (Whitty, Carr 2009, s. 84). Flirty internetowe mogą stanowić formę rozrywki lub zaspokajać potrzebę bycia w związku z inną osobą. Przede wszystkim jednak stwarzają okazję do odnalezienia prawdziwej miłości.

„Romanse online dają szanse na relacje o niskim stopniu ryzyka i dostarczają ekscytacji. Mniejsze ryzyko i mniejsza moralna krytyka takich kontaktów pozwala zaangażowanym osobom uniknąć żalu w krótkiej perspektywie oraz realnego zranienia w dłuższej. Obecność w sieci wielu interesujących partnerów zwiększa dyskomfort braku działań w związku z niesatysfakcjonującym układem offline" (Ben-Ze'ev 2005, s. 111-112). O intensywności romansów internetowych mogą świadczyć postawy młodych użytkowników portali randkowych, którzy pozostawali w tego rodzaju relacjach. „Coraz częściej słyszy się, zwłaszcza u młodych ludzi, że poznali wspaniałą osobę przez internet, na forum dyskusyjnym, czacie bądź na czymś, co nazywa się darmowe randki internetowe. Niektórzy po pierwszej rozmowie skłonni są do stwierdzeń, iż jest to miłość i że pragną związku z tą osobą" (Bartoszewska [online], 12.10.2018).

„Miłość od pierwszego czatu ma związek z «aureolą osobowości» - przypisywaniem osobie posiadającej określony pozytywny rys innych zalet. To jak zakochiwanie się w nieznajomym - nie mamy wszystkich informacji, a luki wypełniamy za pomocą idealizacji" (Ben-Ze'ev 2005, s. 205-206). Aiz Ansari uznał, że "randkowanie w sieci jest jak druga praca wymagająca wiedzy i umiejętności, które niewielu z nas posiada" (Ansari 2016, s. 108). 
Warto zwrócić uwagę na powody, dla których ludzie logują się na portalu randkowym. W Polsce brakuje takich analiz (zwłaszcza w odniesieniu do osób w okresie adolescencji), można jednak odnieść się do badań amerykańskich, które przeprowadziła Monica T. Whitty. Według niej ludzie zakładają konta na portalach randkowych, ponieważ:

$\rightarrow$ liczą na stworzenie długoterminowego związku - odpowiedziało tak aż $91 \%$ respondentów,

$\rightarrow$ portale randkowe są alternatywnym sposobem na poznanie partnera - taki pogląd wyraziła ponad połowa badanych,

$\rightarrow$ portale randkowe pozwalają na szukanie partnera, kiedy inne sposoby (bardziej realne) wywołują niechęć,

$\rightarrow$ nie trzeba się specjalnie przygotowywać i wychodzić z domu,

$\rightarrow$ ludzie czują się pewniej, poznając kogoś w zaciszu domowym, a niechętnie wpuszczają obce osoby do domu,

$\rightarrow$ możliwe jest nawiązanie niezobowiązującej znajomości czy romansu (Whitty, Carr 2009, s. 196).

W cyberprzestrzeni funkcjonuje wiele portali o takim charakterze. Wydawałoby się, że ich użytkownikami są ludzie dorośli. Istnieje jednak mnóstwo serwisów przeznaczonych dla nastolatków, między innymi poszkole.pl, mates.pl, milosnykontakt.pl.

Twórcy portali randkowych przeznaczonych dla nastolatków zastrzegają przy zakładaniu konta, że minimalny wiek użytkownika wynosi trzynaście lat. Jak jednak wskazuje praktyka, warunek ten nie jest przestrzegany. Zdarza się, że użytkownikami tych serwisów są osoby dużo młodsze, ale także bardzo dojrzałe. Przeglądając zakładki, można znaleźć zdjęcia bardzo młodych osób robiących tak zwany dzióbek i prezentujące się w skąpych strojach. Takie zdjęcia otrzymują najwięcej gwiazdek od użytkowników. Pojawiają się wątpliwości i pytania dotyczące poszukiwania znajomych w internecie przez tak młodych użytkowników.

W związku z analizą problematyki portali randkowych należy wspomnieć o aplikacji Tinder, która korzysta z technologii lokalizacji i jest bardzo popularna wśród internautów. Stworzona została pod koniec 2012 r. przez Seana Rada, Justina Mateena i Jonathana Badeena, studentów Uniwersytetu Karoliny Południowej. Jest to aplikacja dostępna w dwudziestu czterech wersjach językowych, umożliwiająca wyszukanie idealnego partnera seksualnego w najbliższej okolicy użytkownika. 
Można nazwać ją speed dating w wersji wirtualnej. Aplikacja jest prosta w obsłudze. Podczas zakładania profilu wstawia się swoje zdjęcia, ustawia obszar wyszukiwania przyszłego partnera, płeć i wiek osoby, której szukamy. Natychmiast pojawiają się zdjęcia (od subtelnych po bardziej odważne). Wchodząc na profil, można zapoznać się ze szczegółowymi danymi na temat danej osoby (na przykład dowiedzieć się, ile dana osoba ma wzrostu lub jaki ma rozmiar biustu). W taki sposób można wybrać partnera (także seksualnego) spełniającego nasze warunki. Kiedy "polubimy" już wybrany profil, czekamy na odzew z drugiej strony. Jeśli osoba ta również wykaże zainteresowanie, otwiera się chat, na którym można rozpocząć rozmowy. Bardziej niecierpliwi użytkownicy mogą od razu umówić się na spotkanie w świecie rzeczywistym.

Popularność Tindera wiąże się z kulturą wygodnej konsumpcji, w której szczególnie młodzi ludzie mają silną potrzebę zaspakajania swoich potrzeb natychmiast, bez zbędnego odraczania i bez nieprzyjemnego napięcia. Sposób przeniesienia znajomości wirtualnej do świata rzeczywistego zależy wyłącznie od chęci, preferencji i nastawienia użytkowników. Internet może przełamywać bariery, popychać do zachowań, które kiedyś nie byłyby akceptowane.

Należy mocno zaakcentować, że młodzi ludzie są często nieświadomi niebezpieczeństw związanych z aktywnością na portalach randkowych i padają ofiarą przekazów erotycznych, a także nierzadko stają się obiektami wykorzystania seksualnego. Z punktu widzenia tych rozważań cenna jest refleksja Sylwii Galanciak: „Czy możliwe jest przeniesienie ukształtowanych w realnym świecie, wypracowanych przez dziesiątki, setki lat więzi społecznych do przestrzeni przez media? Entuzjaści gorliwie przytakną w odpowiedzi, krytycy - przeciwnie - sceptycznie pokręcą głowami. Bez względu jednak na naukowe rozstrzygnięcia i wizje proroków cyfrowego postępu, proces transferu postaw i wartości trwa. Internauci zagospodarowują nową przestrzeń aktywności, nie czekając na werdykt i nie przejmując się diagnozami. Zamiast wieść aksjologiczny spór, trzeba zatem zastanowić się, jak uczynić z użytkowników sieci osoby kompetentne i świadome konsekwencji własnych poczynań. Jak wykorzystać potrzebę społecznej integracji dla tworzenia lepszego, mądrzejszego społeczeństwa. To wielkie wyzwanie stojące przed pedagogiką jutra" (Galanciak 2017, s. 29). 


\section{Zakończenie}

Świat wirtualny jest ważnym miejscem ludzkiego funkcjonowania w wielu obszarach. Na niespotykaną skalę zmienił kontakty interpersonalne. Dla młodych ludzi stał się częścią ich życia. W świecie tym szukają oni nie tylko informacji czy rozrywki, ale także kontaktu z drugim człowiekiem. Nawiązują i utrzymują bliższe oraz dalsze relacje. Czasem udaje im się znaleźć kogoś, kto na trwale pozytywnie wpisze się w ich życie, nierzadko się jednak zdarza, że kontakt z osobą poznaną w przestrzeni cyfrowej okazuje się doświadczeniem negatywnym. Młodzież podchodzi do relacji międzyludzkich w świecie wirtualnym bez pogłębionej refleksji, co uwalnia młodych ludzi spod wpływu kontroli społecznej, stwarzając często różnorodne zagrożenia.

Problematyka ta jest dużym wyzwaniem dla środowiska pedagogicznego, które powinno przygotować najmłodsze pokolenie do nawiązywania właściwych relacji w przestrzeni cyfrowej. Konieczne jest także $w$ tym obszarze zaangażowanie rodziców, ponieważ to właśnie oni są najważniejszymi wychowawcami. 